\title{
Production of highly purified fractions of $\alpha$-lactalbumin and $\beta$-lactoglobulin from cheese whey using high hydrostatic pressure
}

\author{
Alice Marciniak, ${ }^{1}$ Shyam Suwal, ${ }^{1,2}$ Serine Touhami, ${ }^{1}$ Julien Chamberland, ${ }^{1} \odot$ Yves Pouliot, ${ }^{1} \odot$ \\ and Alain Doyen ${ }^{1 *}$ (D) \\ ${ }^{1}$ Institute of Nutrition and Functional Foods (INAF), Dairy Science and Technology Research Centre (STELA), Department of Food Sciences, \\ Université Laval, Quebec City, Quebec, G1V 0A6, Canada \\ ${ }^{2}$ Department of Food Science, Faculty of Science, University of Copenhagen Rolighedsvej 26, DK-1958 Frederiksberg C, Denmark
}

\begin{abstract}
Despite extensive research on the topic, valorization of dairy by-products remains challenging. Cheese whey is of particular interest because it contains valuable proteins such as $\alpha$-lactalbumin ( $\alpha$-LA) and $\beta$-lactoglobulin $(\beta-\mathrm{LG})$. However, selective fractionation of these 2 proteins into pure fractions is complex because of their similar molecular weights. In this study, we proposed an innovative protein separation strategy based on coupling high hydrostatic pressure (HHP) with acidification of whey at $\mathrm{pH}$ 4.6. We investigated the effect of single-cycle HHP (600 MPa) for 5, 10, and $15 \mathrm{~min}$ and multiple-cycle HHP (1-3 cycles of 5 min at $600 \mathrm{MPa}$ ) on $\alpha-\mathrm{LA}$ and $\beta-\mathrm{LG}$ fractionation from cheese whey at initial pH (control, $\mathrm{pH}$ 6.66) and acidified to $\mathrm{pH}$ 4.6. All pressurization conditions with acidified whey induced a drastic aggregation of $\beta$-LG compared with control whey. The highest degrees of purification (75 and 98\%, respectively) and yields (95 and $88 \%$, respectively) of $\alpha$-LA and $\beta$-LG were obtained with the application of single-cycle HHP treatment of acidified whey at $\mathrm{pH} 4.6$ at $600 \mathrm{MPa}$ for $5 \mathrm{~min}$. Our results showed the strong potential of using HHP as an innovative tool for the fractionation of valuable proteins such as $\alpha$-LA from cheese whey.
\end{abstract}

Key words: cheese whey, high hydrostatic pressure, $\alpha$-lactalbumin, $\beta$-lactoglobulin, purification

\section{INTRODUCTION}

In 2013, about 1.5 million tonnes of highly valuable whey proteins (WP) were generated from by-products of cheese, yogurt, and casein production worldwide. The valorization of these proteins is of great economic

Received October 30, 2019.

Accepted April 26, 2020.

*Corresponding author: alain.doyen@fsaa.ulaval.ca and environmental interest (Bylund et al., 2003). Whey is mainly composed of $\beta-\mathrm{LG}$ and $\alpha-\mathrm{LA}$, which represent 50 and $20 \%$ of total WP, respectively. Both proteins have interesting nutritional, functional, and biological properties. Originally, WP were simply disposed of into the environment, which raised environmental concerns. Today, although isolates or concentrates are produced using WP, the fractionation of WP is highly desired because of the high value of individual proteins, although it remains challenging (Smithers, 2015). Numerous works have investigated different approaches to generate $\alpha$-LA and $\beta$-LG fractions with high purity such as chromatography, selective precipitation, and ultrafiltration used alone or in combination (El-Sayed and Chase, 2011; Smithers, 2015). Despite high purification and recovery rates, these methods are time consuming and may generate polluting effluents (DeSilva et al., 2003; Arunkumar and Etzel, 2013; Smithers, 2015).

More recently, research works have focused on innovative nonthermal processes. In this context, Yver et al. (2011) and Lima et al. (2019) used supercritical carbon dioxide to purify $\alpha$-LA from WP isolate. However, these studies reported precipitation and denaturation of $\alpha$-LA that could affect its nutritional, functional, and biological properties. We developed a potentially more sustainable fractionation process based on the application of high hydrostatic pressure (HHP), which does not generate waste that hinders other purification technologies. The HHP process is an emerging technology governed by (1) isostatic, (2) Le Chatelier, and (3) microscopic ordering principles, coupled with acidification at $\mathrm{pH} 4.6$ to separate $\alpha$-LA with $87 \%$ purity from a model whey protein solution (Marciniak et al., 2018b). In our previous work (Marciniak et al., 2018b), we studied the effects of process duration, pressurization level, and use of different ligands (caseins). We demonstrated, in model solutions, that fractionation of $\alpha$-LA and $\beta-L G$ is based on the capacity of HHP (from 200 to $600 \mathrm{MPa})$ to denature $\beta-\mathrm{LG}$ and generate specific aggregates due to the presence of a single free thiol group 
that is normally hidden by the $\alpha$-helix structure of the native protein (Huppertz et al., 2004; Patel et al., 2006; Considine et al., 2007). In addition, we showed that casein, originally used as a ligand to improve $\beta$-LG aggregation, had, contrarily, a chaperone-like effect under pressure treatment (Marciniak et al., 2018a, 2019).

Acidification of WP at $\mathrm{pH} 4.6$ is known to induce formation of $\beta$-LG octamers by cooperative association of 4 dimers, whereas $\alpha$-LA remains in monomer form (Gaucheron, 2004; Laneuville, 2004; Boland et al., 2014). Consequently, high pressure treatment of whey solution acidified at $\mathrm{pH} 4.6$ could induce the aggregation of $\beta-\mathrm{LG}$ while maintaining the solubility of Q-LA in solution (Bylund et al., 2003; Dufour, 2004). A subsequent centrifugation would easily separate the 2 fractions into $\alpha$-LA (supernatant) and $\beta-L G$ (pellet). Therefore, the general objective of this work was to develop a novel HHP-based technology to fractionate WP from a real solution (cheese whey), based on previous findings obtained with model solutions (Marciniak et al., 2018b). To that end, we evaluated the effect of acidification and HHP parameters (treatment time and number of HHP cycles) by (1) studying the changes in conformation of WP, and (2) quantifying yield and purity rates of both $\alpha-\mathrm{LA}$ and $\beta-\mathrm{LG}$.

\section{MATERIALS AND METHODS}

\section{Materials}

Raw cheese whey (not pasteurized, not clarified) from the production of gouda-like cheese (uncooked, pressed cheese involving a curd-washing step) made from pasteurized milk was kindly provided by Fromagerie Bergeron (Saint-Antoine-de-Tilly, QC, Canada). It was filtered through a cheese cloth upon receipt, and divided into 3 batches. Each batch was used for one replicate. Total solids were determined according to method 990.20 (AOAC International, 2005). Total nitrogen, NPN, and noncasein nitrogen contents were determined using the Kjeldahl method, respectively, according to method 991.20, method 930.29, and method 998.06 (AOAC International, 2005). Finally, minerals content was determined by IDF 90:2008 (ISO, 2008). Table 1 summarizes the composition of cheese whey used in this study.

\section{Experimental Methodology}

The experimental design used for WP fractionation is illustrated in Figure 1. Initial whey at pH 6.66 (WpHi) and acidified whey at $\mathrm{pH} 4.6$ ( $\mathbf{W p H a}$ ) before HHP were first transferred into flexible plastic bags for pres- surization experiments in a discontinuous hydrostatic pressurization unit (Hiperbaric 135 L, Hiperbaric, Burgos, Spain) using water as pressure transmission medium. The pressurization rate was $27.5 \mathrm{~s}$ for 100 $\mathrm{MPa}$ and decompression was instantaneous. Both whey solutions ( $\mathrm{WpHi}$ and $\mathrm{WpHa}$ ) were pressure-treated at $600 \mathrm{MPa}$ for $10 \mathrm{~min}\left(\mathrm{P} 2^{\prime}\right)$ and $15 \mathrm{~min}\left(\mathrm{P} 3^{\prime}\right)$ at room temperature. Multi-cycle pressurization (P1, P2, and P3) of 5 min were also tested in the same conditions on both whey solutions. Afterward, all pressure-treated WpHi solutions (P1i to P3'i) were acidified to $\mathrm{pH} 4.6$ and centrifuged at $11,000 \times g$ for $25 \mathrm{~min}$; the pressuretreated $\mathrm{WpHa}$ solutions (P1a to P3'a) were directly centrifuged at $11,000 \times g$ for $25 \mathrm{~min}$. Supernatants of each sample were collected for further analyses.

\section{Turbidity Measurement}

Turbidity of control (WpHi and $\mathrm{WpHa}$ ), pressuretreated (P1 to P3'), and supernatant samples was measured by optical density at $360 \mathrm{~nm}$ (Thermo Labsystems Multiskan Spectrum Microplate UV/VIS reader, ThermoFisher Scientific, Waltham, MA). A volume of $200 \mu \mathrm{L}$ of each sample was analyzed in triplicate in transparent 96-well microplates from Greiner Bio-One (Kremsmünster, Austria) according to Marciniak et al. (2018a).

\section{Determination of Protein Profiles}

Electrophoresis under nonreducing condition (SDSPAGE) was performed on control, pressure-treated, and supernatant samples at each $\mathrm{pH}$ (6.66 and 4.6) to determine the effect of HHP combined with acidification on protein profiles and formation of aggregates. The methodology was as described in our previous work (Marciniak et al., 2018b). Briefly, samples were

Table 1. Composition (\% wt/vol) of gouda-like cheese whey used in the present study

\begin{tabular}{lc}
\hline Constituent & $\begin{array}{c}\text { Composition } \\
(\% \mathrm{wt} / \mathrm{vol})\end{array}$ \\
\hline Moisture & $95.22 \pm 0.03$ \\
Nitrogenous matter & $0.65 \pm 0.00$ \\
pH 4.6-insoluble protein & $0.06 \pm 0.00$ \\
pH 4.6-soluble protein & $0.42 \pm 0.00$ \\
NPN & $0.17 \pm 0.00$ \\
Non-nitrogenous matter & $4.13 \pm 0.03$ \\
Minerals & $0.40 \pm 0.01$ \\
Lactose & $3.49 \pm 0.02$ \\
Other (e.g., residual fat) & $0.24 \pm 0.01$ \\
pH & 6.66 \\
\hline
\end{tabular}

${ }^{1}$ Each value is expressed as mean value $\pm \mathrm{SD}(\mathrm{n}=3)$. 


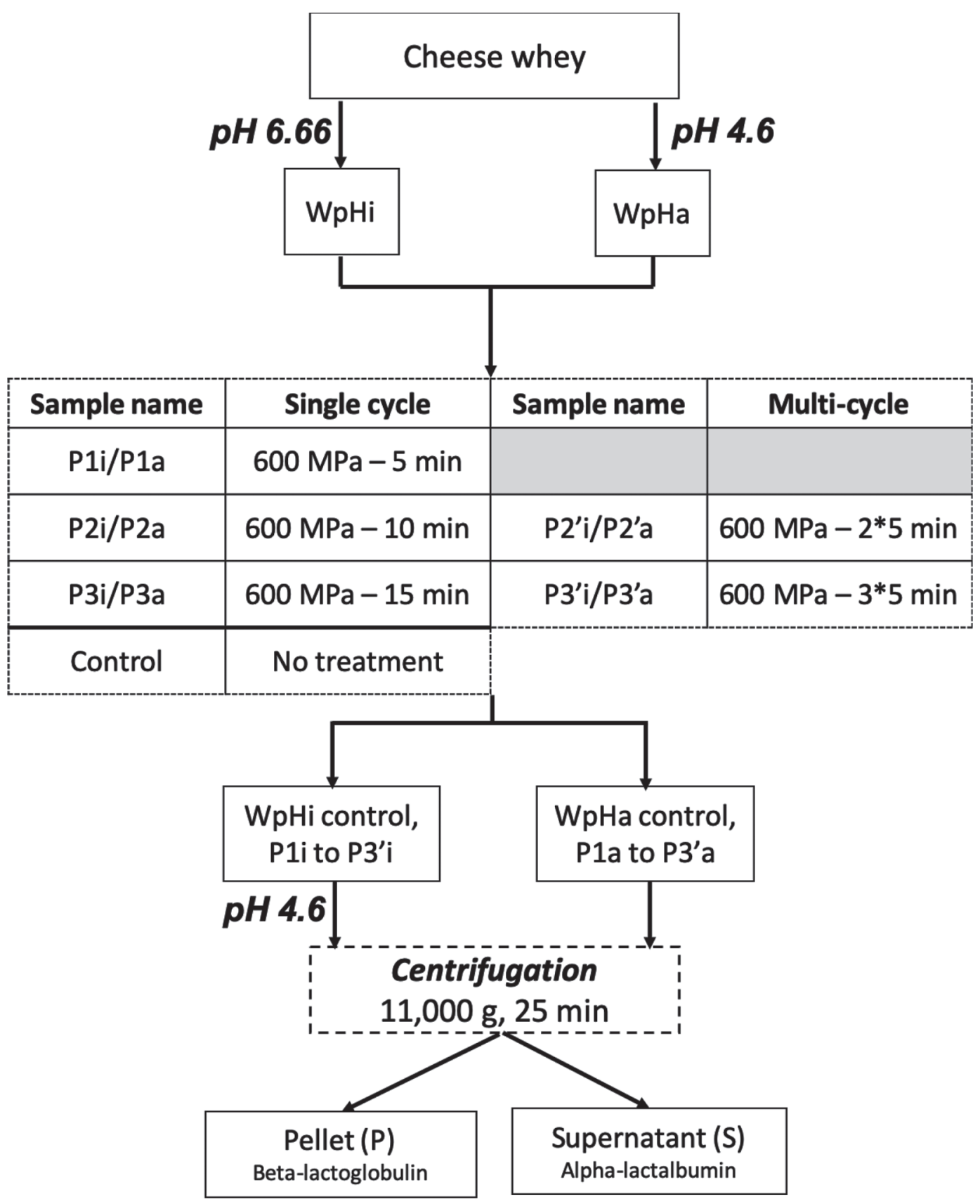

Figure 1. Schematic diagram representing the steps for the fractionation of $\alpha$-LA and $\beta$-LG from gouda-like cheese whey using high hydrostatic pressure. Letters a and i correspond to acidified ( $\mathrm{pH} 4.6$ ) and initial ( $\mathrm{pH}$ 6.66) $\mathrm{pH}$ of cheese whey (W) before pressurization, respectively. P1: sample pressurized for 5 min at $600 \mathrm{MPa}, \mathrm{P} 2: 10 \mathrm{~min}$ at $600 \mathrm{MPa}, \mathrm{P} 3: 15 \mathrm{~min}$ at $600 \mathrm{MPa}, \mathrm{P} 2{ }^{\prime}: 2 \times 5 \mathrm{~min}$ at $600 \mathrm{MPa}$, and P3': $3 \times 5$ min at $500 \mathrm{MPa}$.

loaded onto a $12 \%$ acrylamide gel from Bio-Rad (Hercules, CA) and run for 75 min using SDS Tris-glycine running buffer. Gels were then stained in Coomassie Blue solution and unstained using acetic acid:ethanol: water solution (10:10:80). Images were taken using a ChemiDoc MP camera from Bio-Rad (Marciniak et al., 2018a).

\section{Analysis of Conformational Changes in Proteins}

Effect of HHP on protein structure and denaturation of pressure-treated samples and controls was determined by intrinsic fluorescence measurement using an ISS PC1 photon-counting spectrofluorometer (Champaign, IL). The intrinsic fluorescence of tryptophan residues 
was monitored at an excitation wavelength of $280 \mathrm{~nm}$, and emission spectra were recorded from 280 to $550 \mathrm{~nm}$ as the emission maxima wavelength of tryptophan was $350 \mathrm{~nm}$ (Ghisaidoobe and Chung, 2014).

\section{Determination of $\alpha-L A$ and $\beta-L G$ Concentrations in Supernatants}

After centrifugation, a supernatant enriched in $\alpha-\mathrm{LA}$ and a pellet enriched in $\beta$-LG were recovered. Concentrations of $\alpha-\mathrm{LA}$ and $\beta-\mathrm{LG}$ were determined in supernatants obtained from all conditions tested and analyzed by reverse-phase HPLC (110 Series, Agilent Technologies, Palo Alto, CA) with a gradient of solvent A $(0.10 \% \mathrm{vol} /$ vol trifluoroacetic acid $)$ and solvent B (90\% acetonitrile, $10 \%$ water, $0.10 \%$ trifluoroacetic acid, by volume). Elution was performed on Luna C18 column from Phenomenex (Torrance, CA) at a flow rate of $0.2 \mathrm{~mL} / \mathrm{min}$ at $40^{\circ} \mathrm{C}$. Running parameters were as described by Marciniak et al. (2018b). Concentrations of $\alpha-\mathrm{LA}$ and $\beta-\mathrm{LG}$ were determined using area under the curve of a peak and compared with standard solutions of $\alpha$-LA and $\beta$-LG (Agropur Ingredients, Le Sueur, MN).

Because the pellets were difficult to resuspend, $\beta$-LG recoveries and purities in this fraction were calculated by difference between the content in initial whey and supernatants of pressure-treated samples, whereas $\alpha$-LA recoveries and purities in supernatant were calculated directly, as described by the following equations:

$\alpha$-LA recovery yield $(\%)=\frac{[\alpha-\mathrm{LA}]_{\mathrm{s}}}{[\alpha-\mathrm{LA}]_{\mathrm{c}}} \times 100$

$\beta$-LG recovery yield $(\%)=100-\frac{[\beta-\mathrm{LG}]_{\mathrm{S}}}{[\beta-\mathrm{LG}]_{\mathrm{C}}} \times 100$,

$\alpha$-LA purification degree $(\%)=\frac{[\alpha-\mathrm{LA}]_{\mathrm{S}}}{[\alpha-\mathrm{LA}]_{\mathrm{S}}+[\beta-\mathrm{LG}]_{\mathrm{S}}} \times 100$

$\beta$-LG purification degree $(\%)=$

$$
\frac{[\beta-\mathrm{LG}]_{\mathrm{c}}-[\beta-\mathrm{LG}]_{\mathrm{S}}}{\left([\alpha-\mathrm{LA}]_{\mathrm{c}}-[\alpha-\mathrm{LA}]_{\mathrm{S}}\right)+\left([\beta-\mathrm{LG}]_{\mathrm{c}}-[\beta-\mathrm{LG}]_{\mathrm{S}}\right)} \times 100,
$$

where $[\alpha-\mathrm{LA}]$ and $[\beta-\mathrm{LG}]$ correspond to the concentration (expressed in $\mathrm{mg} / \mathrm{mL}$ ) of $\alpha-\mathrm{LA}$ or $\beta-\mathrm{LG}$ in supernatant (s) and controls from $\mathrm{pHi}$ and $\mathrm{pHa}$ (c) whey samples, which had the same protein content (and in- directly the same denaturation degree of whey protein) as the initial whey $(P>0.05)$.

Because of the quantification method used and the aim of the work, purification degrees of $\alpha-\mathrm{LA}$ and $\beta-\mathrm{LG}$ were calculated in relation to each other, without considering other minor proteins.

\section{Statistical Analysis}

All experiments and analysis were performed in triplicate; SAS Studio 3.5 software (University edition, SAS Institute Inc., Cary, NC) was used to perform statistical analyses. For degrees of purity and yield of $\alpha$-LA in supernatant, we used a randomized complete block design with 7 treatments: control (not pressure-treated, $\mathrm{WpHi}$ and $\mathrm{WpHa}$ ) and supernatants of control (P1i/ P1a, P2i/P2a, P3i/P3a, P2'i/P2'a, and P3'i/P3'a) in multiple blocks $(\mathrm{n}=3)$ for each $\mathrm{pH}$ value: initial (i; $\mathrm{pH}$ 6.66) and acidified (a; pH 4.6). For purity and yield of $\beta$-LG in pellet, we used a randomized complete block design with 5 treatments (P1i/P1a, P2i/P2a, P3i/P3a, P2'i/P2'a, and P3'i/P3'a) in triplicate for samples at both pH: initial (i) and acidified (a). Multiple comparison tests were performed using Tukey tests $(\alpha=0.05)$ to compare controls (non-pressure-treated samples) with HHP-treated samples. Factorial analysis of $2 \times$ 3 levels ( $\mathrm{pH} \times$ number of cycles) was performed to determine the effect of $\mathrm{pH}$ and number of HHP cycles on protein purity and yield.

\section{RESULTS AND DISCUSSION}

\section{Effect of HHP and pH on Solution Turbidity}

Visual appearance of control, pressure-treated, and supernatant samples of whey solutions are presented in Figure 2. The apparent turbidity of pressure-treated (P1, P2, P2', P3, and P3') samples at both initial (i) and acidified $\mathrm{pH}$ (a) was higher than that of control samples (WpHi and WpHa). Furthermore, the apparent turbidity of whey at the initial $\mathrm{pH}$ (P1i to P3'i) increased gradually with the increase in number of HHP cycles and pressurization time. In addition, the turbidity of supernatant samples generated from HHPtreated samples decreased considerably after acidification and centrifugation and remained similar to the non-pressure-treated control sample (WpHi). Concerning whey acidified at $\mathrm{pH} 4.6$ (control $\mathrm{WpHa}$ and $\mathrm{P} 1 \mathrm{a}$ to P3'a), the resulting turbidity was similar regardless of the number of cycles and pressurization duration (P1a, P2a, P3a, P2'a, and P3'a). In general, the HHP treatment of acidified samples (right and upper) resulted in more turbid solutions than did HHP of initial $\mathrm{pH}$ samples. 

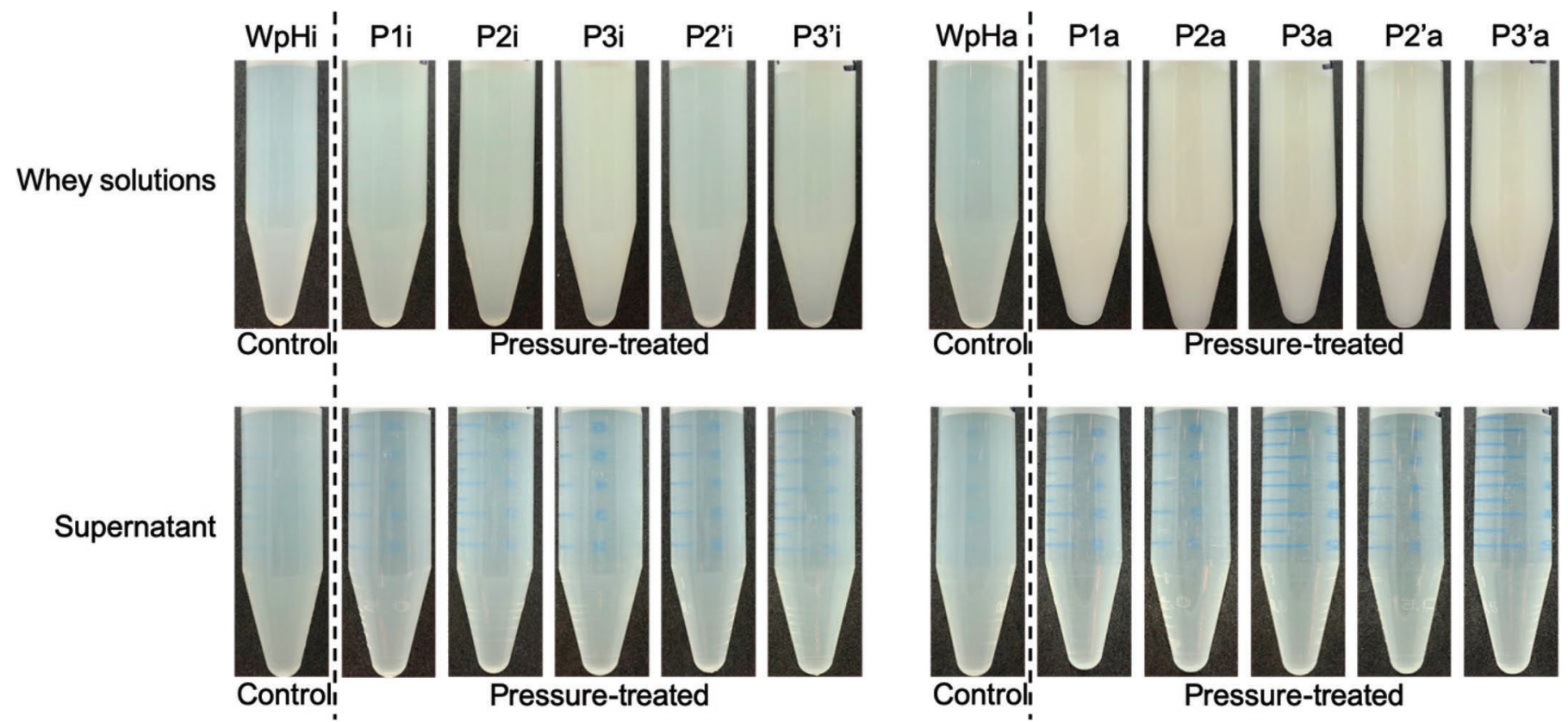

Figure 2. Visual appearance before (control) and after high hydrostatic pressure (pressure-treated) of whey (W) solutions (upper panels), at initial $\mathrm{pH}$ ( $\mathrm{pHi}$, left) and 4.6 (pHa, right) and after centrifugation (supernatant; lower panels). Letters a and i correspond to acidified (pH 4.6) and initial (pH 6.66) $\mathrm{pH}$ of cheese whey before pressurization, respectively. P1: sample pressurized for 5 min at $600 \mathrm{MPa}, \mathrm{P} 2: 10 \mathrm{~min}$ at 600 $\mathrm{MPa}, \mathrm{P} 3: 15 \mathrm{~min}$ at $600 \mathrm{MPa}, \mathrm{P} 2^{\prime}: 2 \times 5$ min at $600 \mathrm{MPa}$, and P3': $3 \times 5$ min at $500 \mathrm{MPa}$.

Turbidity was generally correlated with protein aggregation, which was measured by optical density (OD) at $360 \mathrm{~nm}$. Figure 3 shows OD values of controls (WpHi and $\mathrm{WpHa}$; black), pressure-treated whey samples (light gray), and resulting supernatants (dark gray) at various numbers of HHP cycles and pressurization at $\mathrm{pH} 6.66$ and 4.6. First, we noted that the turbidity of the supernatants of both controls ( $\mathrm{WpHi}$ and $\mathrm{WpHa}$ ) decreased slightly after centrifugation. As whey was only filtered with a cheese cloth before the experiments, it still contained insoluble cheese artifacts (i.e., cheese fines) that were precipitated during centrifugation. However, because the protein contents of initial whey (WpHi and $\mathrm{WpHa}$ ) were not significantly different, we hypothesize that the increase in residual fat or deposition of remaining starter culture during centrifugation might have contributed to the reduced turbidity of centrifuged samples. Moreover, the OD value of the control at $\mathrm{pH} 4.6$ (WpHi) was slightly higher than that at $\mathrm{pH}$ 6.66 , which could be due to the formation of octamers of $\beta-\mathrm{LG}$ at acid $\mathrm{pH}$ compared with dimers at neutral pH (Gaucheron, 2004; Laneuville, 2004).

Regarding the effect of number of HHP cycles (Figure $3 \mathrm{~A}$ ), we observed an increase in $\mathrm{OD}$ value with the increase in the number of pressurization cycles only for the samples at initial $\mathrm{pH}(\mathrm{P} 1 \mathrm{i}, \mathrm{P} 2 \mathrm{i}$, and P3i). The OD varied from $1.36 \pm 0.12$ for P1i ( 1 cycle) to $2.00 \pm 0.03$ for P3i (3 cycles). In contrast, samples pressurized at
$\mathrm{pH} 4.6$ did not show any differences in OD, regardless of the number of cycles $(P>0.05)$. Intensity of absorbance increased to $2.72 \pm 0.02$ on average (P1a,

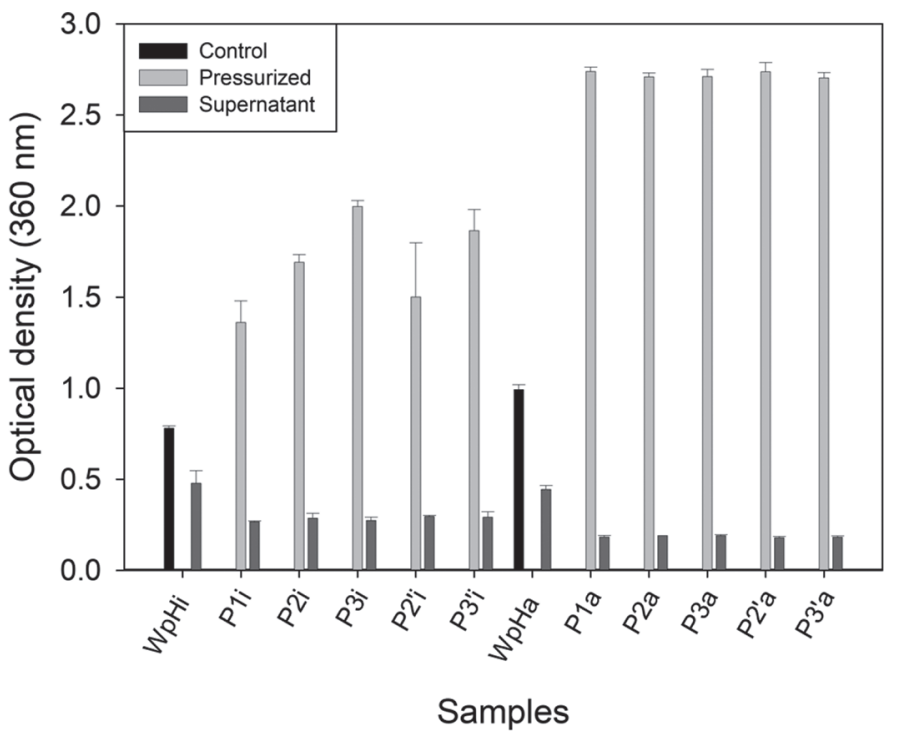

Figure 3. Optical density measured at $360 \mathrm{~nm}$ of controls (black bars), pressure-treated whey (W) solutions (light gray bars), and resulting supernatants (dark gray bars) at initial (i) and acidified (a) $\mathrm{pH}$. Optical density is represented in function of number of cycles. P1: sample pressurized for $5 \mathrm{~min}$ at $600 \mathrm{MPa}, \mathrm{P} 2: 10 \mathrm{~min}$ at $600 \mathrm{MPa}, \mathrm{P} 3$ : 15 min at $600 \mathrm{MPa}, \mathrm{P}^{\prime}: 2 \times 5 \mathrm{~min}$ at $600 \mathrm{MPa}$, and $\mathrm{P} 3^{\prime}: 3 \times 5 \mathrm{~min}$ at $500 \mathrm{MPa}$ 
$\mathrm{P} 2 \mathrm{a}$, and P3a) compared with $0.78 \pm 0.01$ for $\mathrm{WpHi}$ control and with $0.99 \pm 0.03$ for WpHa control. Last, regardless of the number of pressurization cycles and $\mathrm{pH}, \mathrm{OD}$ values of all supernatants were similar: $0.28 \pm$ 0.01 and $0.19 \pm 0.00$, respectively, for $\mathrm{pH} 6.66$ and 4.6 $(P<0.05)$.

Samples undergoing the single-cycle treatment (P1, P2, and P3) at different treatment times (Figure 3) showed a similar trend as samples undergoing multicycle treatment. Indeed, for samples at $\mathrm{pH} 6.66$, the OD value increased with the duration of treatment from $1.36 \pm 0.12(\mathrm{P} 1 \mathrm{i}, 5 \mathrm{~min})$ to $1.87 \pm 0.12$ (P3'i, $15 \mathrm{~min}$ ). Similarly, samples pressurized once at $\mathrm{pH} 4.6$ followed the same trend as multi-cycle treatment with an average of $2.73 \pm 0.02$ compared with $0.99 \pm 0.03$ for $\mathrm{WpHa}$ control. As observed for multi-cycle treatments (P2' and P3'), OD values of supernatant from single-cycle samples were higher for samples at initial $\mathrm{pH}$ (average of $0.28 \pm 0.02$ ) than for samples at acidified $\mathrm{pH}$ (average of $0.18 \pm 0.00$ ).

Finally, multi-cycle or single-cycle treatment did not affect OD value trends for samples at either $\mathrm{pH}$. Results for initial $\mathrm{pH}$ (6.66) suggest that after one cycle of pressurization, the effect of time is more important than the effect of pressure. Conversely, for samples pressurized at $\mathrm{pH} 4.6$, no difference was observed $(P>$ $0.05)$, regardless of the number of cycles or the time, suggesting that after one cycle, there is no cumulative effect of pressure or time.

The increase in turbidity after HHP treatment suggested insoluble aggregation of the most sensitive proteins in whey (Bhattacharyya and Das, 1999). Under heat treatment, both $\alpha-\mathrm{LA}$ and $\beta$-LG form aggregates that affect turbidity. However, we expected that HHP treatment would affect $\beta$-LG the most because of its more flexible structure and the presence of interaction sites (hydrophobic and covalent) compared with $\alpha$-LA. Affecting one or more of these chemical properties promotes self-aggregation of $\beta$-LG (Patel et al., 2006; Considine et al., 2007). Moreover, acidification at $\mathrm{pH} 4.6$ before pressurization also potentially altered the $\beta$-LG structure, because at this $\mathrm{pH}, \beta-\mathrm{LG}$ is known to form an octamer that initiates the aggregation reaction. Nevertheless, some precautions are needed concerning optical density and turbidity results: a nonlinear relationship between turbidity and protein aggregation could exist because the former also depends on the shape or form of aggregates (Hall et al., 2016; Marciniak et al., 2018a).

\section{Effect of HHP on Protein Profile}

Protein profiles of control $(\mathrm{WpH})$ and pressuretreated whey $\left(\mathrm{P} 1, \mathrm{P} 2, \mathrm{P} 3, \mathrm{P} 2{ }^{\prime}\right.$, and $\left.\mathrm{P} 3^{\prime}\right)$ at initial $\mathrm{pH}$ and after acidification to $\mathrm{pH} 4.6$, as well as resulting supernatants obtained after centrifugation, were analyzed qualitatively by nonreducing SDS-PAGE (Figure 4). Identification of whey proteins in all samples was based on information related to standard solutions of $\alpha-\mathrm{LA}$ and $\beta$-LG.

All different WP present in cheese whey were observed in the control (WpHi) and its respective supernatant. Among them, and as expected, $\alpha-\mathrm{LA}$ and $\beta-\mathrm{LG}$ did not seem to be affected by the acidification and centrifugation steps because protein profiles and band intensities seemed similar for the control and its supernatant. Focusing on those 2 major WP, the band intensity corresponding to $\alpha$-LA remained stable regardless of the pressurization conditions and acidification or centrifugation for all samples pressurized at initial $\mathrm{pH}$ and their respective supernatants. Concerning the $\beta$-LG band, a slight decrease in intensity was observed for each treatment that could correlate to a decrease in the amount of $\beta$-LG under its native form. Indeed, this decrease was correlated with the slightly darker new bands observed in regions $\mathrm{X}_{1}$ and $\mathrm{X}_{2}$ (Figure 4) for pressure-treated samples, respectively, for aggregates with molecular weights of $<250$ and $>250 \mathrm{kDa}$. The absence of these spots $\left(\mathrm{X}_{1}\right.$ and $\left.\mathrm{X}_{2}\right)$ corresponding to supernatants of each pressure-treated sample indicated precipitation of those aggregates after acidification and centrifugation.

Concerning samples acidified before HHP treatment, we observed that $\mathrm{WpHa}$ was similar to $\mathrm{WpHi}$, indicating that acidification itself did not affect WP. Nevertheless, the effects observed on pressure-treated samples were more visible and distinct for samples pressurized at $\mathrm{pH}$ 4.6 (P1a to P3'a) than for those pressurized at $\mathrm{pH} 6.66$ (P1i to P3'i). Indeed, for those samples (acidified $\mathrm{pH}$ ), no difference was observed in terms of band intensity for $\alpha-L A$, whereas that of $\beta-L G$ was drastically decreased after HHP treatment. As expected, this severe decrease in band intensity was correlated with the appearance of bands in both regions $\mathrm{X}_{1}$ and $\mathrm{X}_{2}$. Interestingly, none of the respective supernatants for acid $\mathrm{pH}$ samples (4.6) showed any high-molecular-weight aggregates. This indicates that aggregates mainly composed of $\beta-\mathrm{LG}$ were precipitated into the pellet whereas $\alpha$-LA remained soluble in the supernatant.

Nonreducing SDS-PAGE analysis clearly showed the impact of pressure and $\mathrm{pH}$ before pressurization on the different WP. As widely described in the literature, HHP, and here, acidification and centrifugation steps, had no effect on $\alpha$-LA because this protein is highly resistant to HHP due to its structural rigidity related to the presence of 4 disulfide bonds in its ternary structure (Considine et al., 2007; McSweeney and O'Mahony, 2016; Huppertz et al., 2019). In contrast, as described previously, $\beta$-LG is more sensitive to HHP due to the 

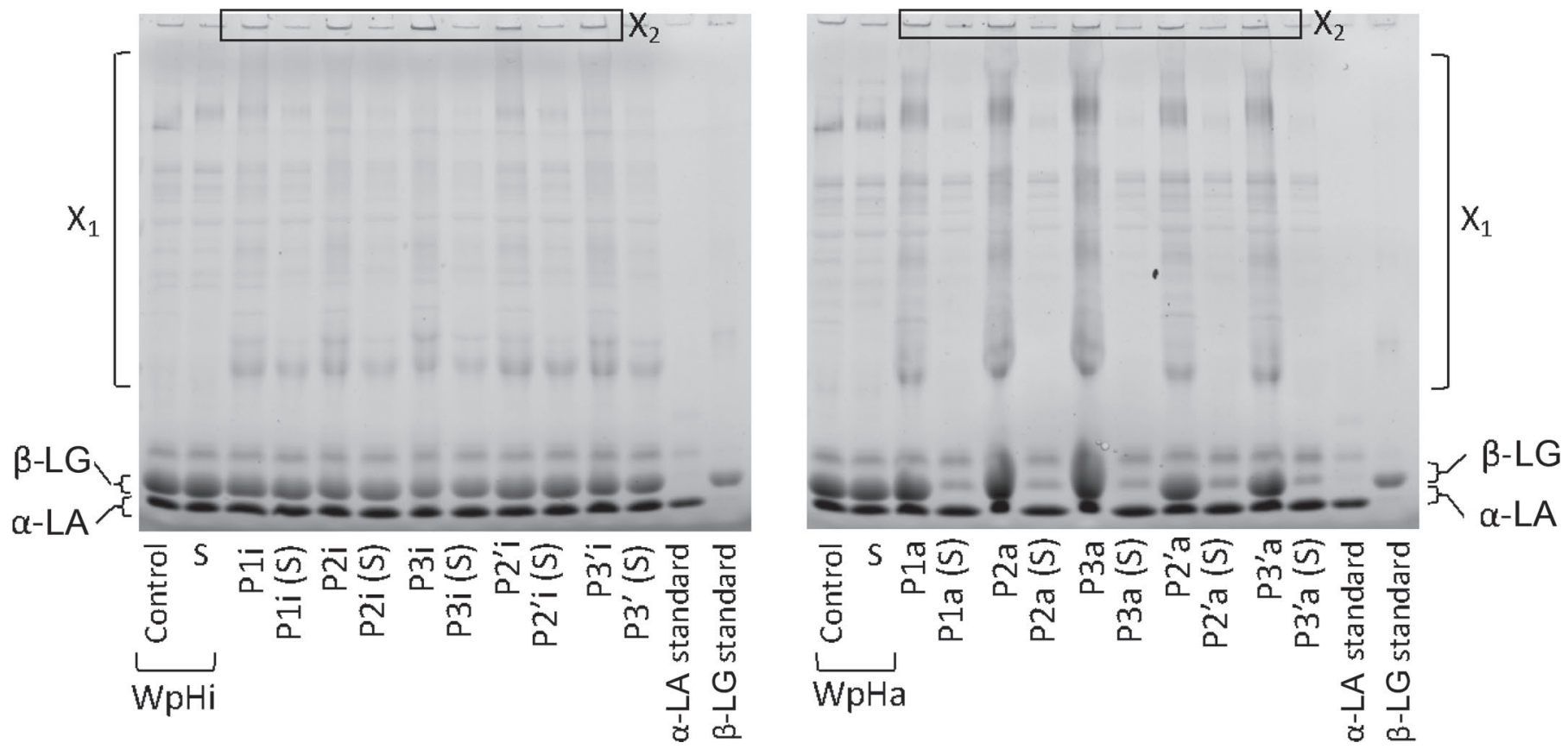

Figure 4. Sodium dodecyl sulfate-PAGE under nonreducing conditions of control and pressurized solutions (P) and supernatants (S). Aggregates $<250 \mathrm{kDa}$ are shown in the $\mathrm{X}_{1}$ region and larger aggregates $(>250 \mathrm{kDa})$ are shown in box $\mathrm{X}_{2}$. Letters a and i correspond to acidified $(\mathrm{pH} 4.6)$ and initial $(\mathrm{pH}$ 6.66) $\mathrm{pH}$ of cheese whey (W) before pressurization, respectively. P1: sample pressurized for 5 min at $600 \mathrm{MPa}$, P2: 10 min at $600 \mathrm{MPa}, \mathrm{P} 3: 15 \mathrm{~min}$ at $600 \mathrm{MPa}, \mathrm{P} 2$ ': $2 \times 5$ min at $600 \mathrm{MPa}$, and P3': $3 \times 5$ min at $500 \mathrm{MPa}$.

presence of only 2 disulfide bonds. Also, the presence of its hydrophobic pocket and free thiol residue (Cys-121) promotes disulfide bond and hydrophobic interchange between the proteins, facilitating its aggregation ( $\mathrm{Pa}$ tel et al., 2006; Huppertz et al., 2019). Aggregation of $\beta$-LG was more intense for pressure-treated samples at $\mathrm{pH} 4.6$, confirming that $\mathrm{pH}$ destabilizes $\beta-\mathrm{LG}$, making it even more sensitive to pressure. Differences observed in terms of $\beta-\mathrm{LG}$ aggregation after HHP treatment at different $\mathrm{pH}$ can be explained by the form of the protein at this $\mathrm{pH}$. Indeed, $\beta$-LG proteins are mainly in dimeric form at $\mathrm{pH} 6.66(\mathrm{pHi})$, whereas formation of octamers is enhanced at $\mathrm{pH} 4.6$ (pHa) (Bylund et al., 2003; Dufour, 2004).

To understand the mechanism of $\beta$-LG denaturation and aggregation under pressurization at both $\mathrm{pH}$ values, the intrinsic fluorescence emission of the indole group of tryptophan was measured for control and pressure-treated solutions at both $\mathrm{pH}$. Figure 5 shows the fluorescence emission spectra of tryptophan excited at $280 \mathrm{~nm}$ of solutions at initial (Figure 5A) and acidified $\mathrm{pH}$ (Figure 5B). The emission wavelength maxima of whey (control) and pressure-treated solutions are presented in Figure 6. An increase in fluorescence intensity is associated with a change in protein conformation that exposes more tryptophan (a nonpolar amino acid) residues on the surface of the protein, whereas a shift of the wavelength of emission maxima toward a higher value (also known as red shift), is related to the unfolding of the protein (Lakowicz, 2006).

The acidification of whey to $\mathrm{pH} 4.6$ (WpHa) slightly increased (1.2 times) the fluorescence intensity compared with $\mathrm{WpHi}$, suggesting some degree of change in protein conformation (Figure 5A and B). However, we observed no change in the wavelength of emission maxima after acidification of the whey, signifying no protein unfolding or aggregation (Figure 6A and B). For pressure-treated solutions at pHi, HHP treatment increased the intensity of fluorescence from 1.67 to 1.83 times compared with the untreated control samples. In agreement with the results discussed above for turbidity (Figures 2 and 3) and protein profile (Figure 4), multiple cycles of pressurization applied on whey at initial $\mathrm{pH}\left(\mathrm{P} 2{ }^{\prime} \mathrm{i}\right.$, and $\left.\mathrm{P} 3^{\prime} \mathrm{i}\right)$ had greater effect on protein structure than single-cycle treatments (P2i, and P3i) for the same duration of pressurization (Figure 5A). Similarly, the pressurization of acidified whey (Figure 5B) increased fluorescence intensity from 1.76 to 1.83 times compared with WpHi. However, we observed no clear difference between the number of cycles and duration of pressurization (Figure 5B). Nevertheless, treatment with 3 cycles of pressurization at $\mathrm{pHa}$ was the most severe condition, increasing fluorescence intensity by 2.2 times compared with $\mathrm{WpHi}$. 

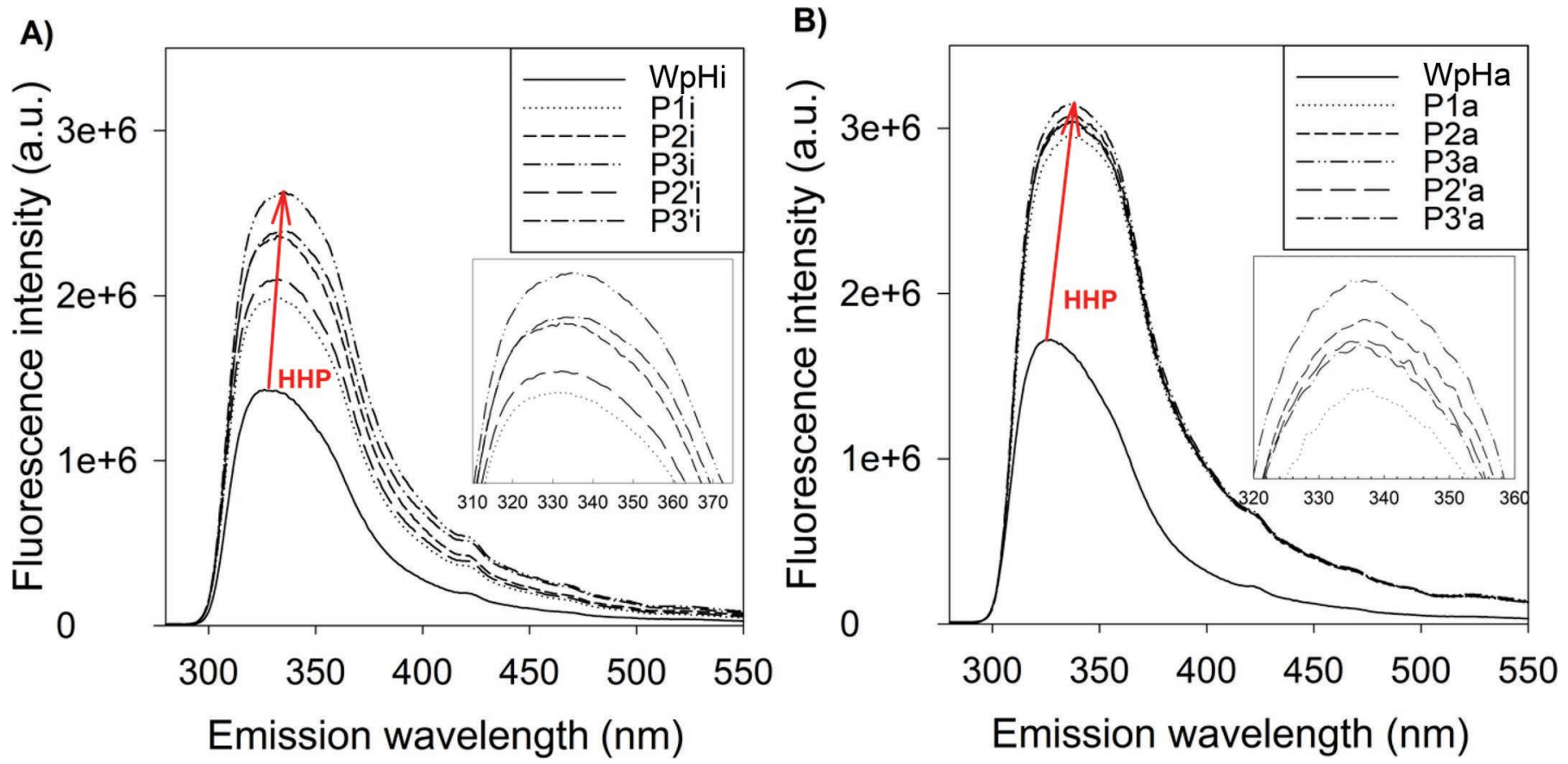

Figure 5. Intrinsic fluorescence spectra of control $(\mathrm{WpH})$ and pressure-treated samples at pHi $(\mathrm{A})$ and $\mathrm{pHa}(\mathrm{B})$, where a and i correspond to acidified $(\mathrm{pH} \mathrm{4.6)}$ and initial $(\mathrm{pH}$ 6.66) $\mathrm{pH}$ of cheese whey before high hydrostatic pressure (HHP) treatment, respectively. P1: sample pressurized for $5 \mathrm{~min}$ at $600 \mathrm{MPa}, \mathrm{P} 2: 10 \mathrm{~min}$ at $600 \mathrm{MPa}, \mathrm{P} 3: 15 \mathrm{~min}$ at $600 \mathrm{MPa}, \mathrm{P} 2^{\prime}: 2 \times 5$ min at $600 \mathrm{MPa}$, and P3': $3 \times 5$ min at $500 \mathrm{MPa}$.

In addition to the increase in fluorescence intensity, pressurization resulted in red shift in the emission spectra that was strongly dependent on the initial $\mathrm{pH}$ of whey as well as the number of cycles (Figure 6A) and the duration of pressurization (Figure 6B). Broadly, pressurization at $\mathrm{pHa}$ resulted in a significantly greater red shift $(>10 \mathrm{~nm})$ and thus greater unfolding of protein than pressurization at $\mathrm{pHi}$, for which the shift was $<7 \mathrm{~nm}$ (Figure 6A and B). Indeed, in the folded state of most proteins, the maximum emission wavelength is around $330 \mathrm{~nm}$ or less, meaning that tryptophan in the molecules is buried inside. Nevertheless, unfolded proteins, and thus available tryptophan, show a maximum of emission wavelength of 350 to $355 \mathrm{~nm}$. Thus, a higher maximum emission wavelength indicates a higher unfolded state of the protein (Royer, 1995; Rodiles-López et al., 2010). Moreover, for the acidified whey samples, even the least severe HHP treatment was sufficient to unfold the protein to the maximum level. In contrast, for samples at initial $\mathrm{pH}$, protein unfolding was related to the severity of the treatment (both number of cycles and time).

As observed in previous nonreducing SDS-PAGE results (Figure 5), and in agreement with the literature, the difference in terms of fluorescence intensity would be mainly due to the denaturation of $\beta-L G$ exposing its hydrophobic domains (Meng et al., 2017). Meng et al. (2017) showed that HHP treatment of pure $\beta$-LG between 100 and $500 \mathrm{MPa}$ for 30 min largely increased the surface hydrophobicity measured by spectrofluorometry, confirming the high structural modification of the protein under isostatic pressure. In contrast to results for $\beta$-LG, Rodiles-López et al. (2010) showed that only acidification at a very low $\mathrm{pH}$ (3) of pure $\alpha$-LA solution generates a $25 \%$ increase of fluorescence intensity due to the exposure of hydrophobic residues in the molten globule state, whereas pressurization does not affect intensity values. Moreover, pressurization of $\alpha$-LA solution at $\mathrm{pH} 5$ and 7 (close to the isoelectric point of $\beta$-LG and the $\mathrm{pH}$ used in our study) did not show any difference in term of fluorescence intensity (Rodiles-López et al., 2010). This statement indicates that fluorescence intensity change observed here was mainly due to $\beta$-LG structure modifications, in accordance with the results observed in nonreducing SDSPAGE analysis (Figure 5).

\section{Protein Yields and Purification Degrees}

The $\alpha$-LA (Table 2) and $\beta$-LG (Table 2) contents of pressure-treated supernatant as well as controls ( $\mathrm{WpHi}$ and $\mathrm{WpHa}$ ) and their respective supernatants were quantified to calculate the degrees of purity and recovery yields. Concerning $\alpha$-LA, controls (nonpressurized samples) at both $\mathrm{pH}(\mathrm{WpHi}$ and $\mathrm{WpHa}$ ) showed very similar recovery yields (100\% for both $\mathrm{pH}$ ) and degrees 
A

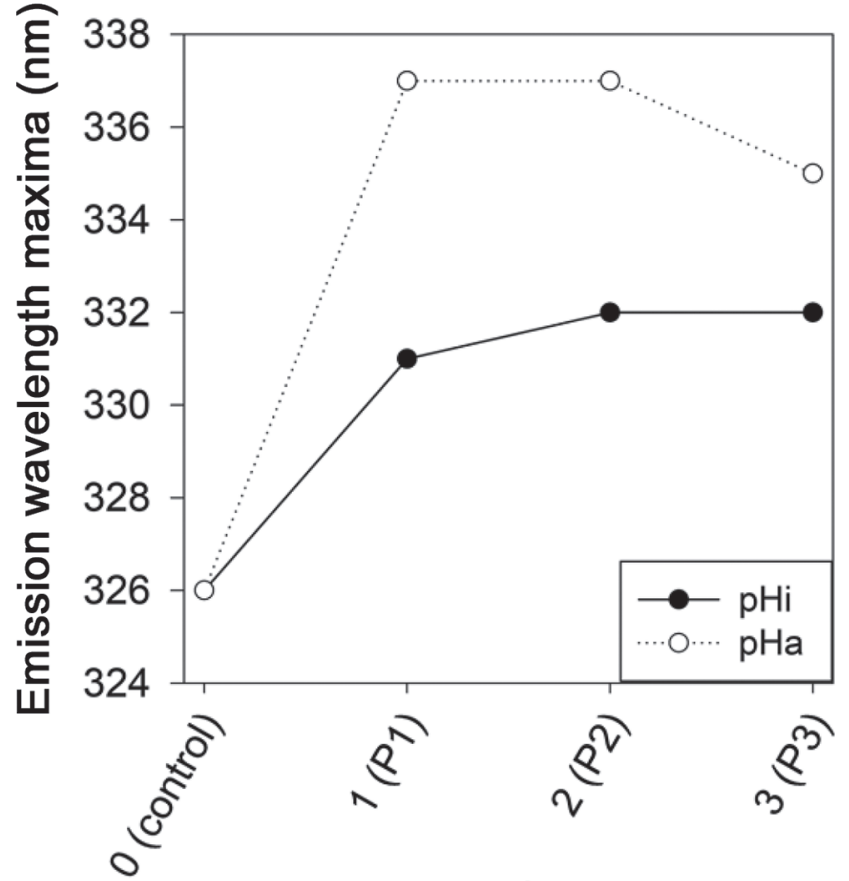

Number of cycles
B)

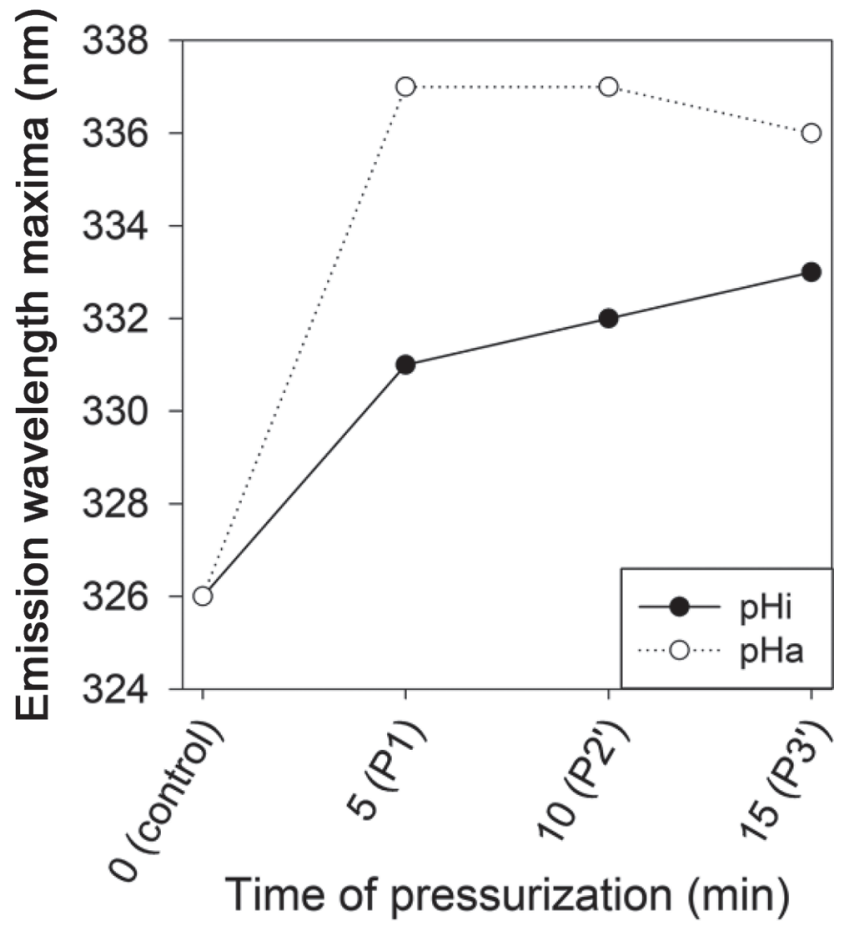

Figure 6. Values of maxima of emission spectra for control and pressure-treated solutions as the function of (A) number of cycles, from 1 (P1) to 3 (P3) cycles, and (B) time of pressurization, from 5 min (P1) to 15 min (P3'). pHa and pHi correspond to acidified (pH 4.6) and initial $(\mathrm{pH} 6.66) \mathrm{pH}$ of cheese whey before high hydrostatic pressure treatment, respectively.

of purity $(28 \pm 0.78 \%$ and $27 \pm 0.83 \%$, respectively, for $\mathrm{WpHi}$ and WpHa; $P>0.05)$. Moreover, protein yields and purification of supernatants of the controls were nonsignificantly different from the initial original whey. This confirms that the acidification and centrifugation steps do not affect the solubility of either $\alpha-L A$ and $\beta$-LG. Regardless of the treatment (duration of pressurization and number of cycles) as well as the $\mathrm{pH}$ before pressurization, $\alpha$-LA protein yield remained similar to that of control. These results confirm the high stability of $\alpha$-LA to HHP treatment because of its tertiary structure, which is stabilized with 4 disulfide bonds, and its lack of reactive thiol free residues (Patel et al., 2006). In contrast, purification degrees in the supernatant were significantly higher for pressure-treated whey samples at $\mathrm{pH} 4.6$ (Table 2; P1a to P3'a; $P<0.05$ ) compared with the corresponding samples pressurized at pH 6.66 (Table 2; P1i to P3'i). Furthermore, and as observed previously with the fluorescence measurement and nonreducing SDS-PAGE analysis, no difference $(P>0.05)$ was observed for $\alpha$-LA purification degrees for samples at $\mathrm{pH} 4.6$, regardless of the HHP treatment. The average purification degree of HHP-treated whey at acid $\mathrm{pH}$ (P1a to P3'a) was $78 \%$ on average, compared with $27 \pm 0.83 \%$ for the control (WpHa).
Conversely, pressurization of whey at 6.66 (P1i to P3'i) increased very slightly but significantly $(P<0.0001)$ the purification degree of $\alpha$-LA from $28 \pm 0.78$ to $38 \pm$ $0.35 \%$ for control to P3i (the severest HHP treatment).

The purification degree of $\beta-\mathrm{LG}$ and yield in the pellet was quantified by difference with the remaining concentration in supernatant (Table 3). No concentration was determined for $\mathrm{WpHi}$ and $\mathrm{WpHa}$ because $\beta$-LG concentration did not change in the supernatant after acidification and centrifugation, meaning no pellet was produced. Results show that purification degrees were similar regardless of the $\mathrm{pH}$ of whey solutions $(6.66$ or 4.6) and pressurization conditions (P1 to $\left.\mathrm{P} 3^{\prime}\right)$, with an average value of $98 \%$ for P1a to P3'a, and $96 \%$ for P1i to P3'i. Consequently, HHP induced very selective precipitation of $\beta-\mathrm{LG}$ at both $\mathrm{pH}$. These results are in strong agreement with our previous study and literature on the effect of HHP on whey protein (Marciniak et al., 2018a; Huppertz et al., 2004). Nevertheless, the pH before pressurization had a significant effect on protein yield in the pellet $(P>0.05)$. Similarly to the purification degree of $\alpha-\mathrm{LA}$, the yield of $\beta$-LG was dependent on both number of pressurization cycles (P1, P2, and P3) and the duration of HHP (P1, P2', and P3') when the experiment was carried out with whey at its initial 
Table 2. $\alpha$-Lactalbumin purification degree and yields (\%) of supernatants (S) recovered from initial (WpHi control) and acidified (WpHa control) whey of pressure treatments (P1, P2, P3, P2', P3') compared with their respective controls ${ }^{1}$

\begin{tabular}{llcc}
\hline pH & Sample name & Pield (\%) & $\begin{array}{c}\text { Purification } \\
\text { degree (\%) }\end{array}$ \\
\hline Initial (6.66) & WpHi (control) & $100.00 \pm 0.00^{\mathrm{a}}$ & $27.89 \pm 0.78^{\mathrm{a}}$ \\
& WpHi (S) & $100.21 \pm 2.80^{\mathrm{a}}$ & $27.39 \pm 0.61^{\mathrm{a}}$ \\
& P1i (S) & $96.21 \pm 2.01^{\mathrm{a}}$ & $31.28 \pm 0.39^{\mathrm{b}}$ \\
P2i (S) & $97.16 \pm 2.54^{\mathrm{a}}$ & $34.94 \pm 0.76^{\mathrm{c}}$ \\
P3i (S) & $97.87 \pm 3.71^{\mathrm{a}}$ & $38.35 \pm 0.35^{\mathrm{d}}$ \\
& P2'i (S) & $99.96 \pm 3.96^{\mathrm{a}}$ & $32.66 \pm 0.76^{\mathrm{b}}$ \\
& P3'i (S) & $97.32 \pm 1.80^{\mathrm{a}}$ & $35.75 \pm 1.14^{\mathrm{c}}$ \\
& & \\
WpHa (control) & $100 \pm 0.00^{\mathrm{a}}$ & $26.88 \pm 0.83^{\mathrm{a}}$ \\
& WpHa (S) & $100.48 \pm 0.58^{\mathrm{a}}$ & $26.95 \pm 0.82^{\mathrm{a}}$ \\
& P1a (S) & $94.97 \pm 1.41^{\mathrm{a}}$ & $74.78 \pm 1.94^{\mathrm{b}}$ \\
& P2a (S) & $98.20 \pm 2.22^{\mathrm{a}}$ & $79.62 \pm 2.41^{\mathrm{b}}$ \\
P3a (S) & $96.15 \pm 4.00^{\mathrm{a}}$ & $81.55 \pm 2.13^{\mathrm{b}}$ \\
P2'a (S) & $96.80 \pm 1.11^{\mathrm{a}}$ & $75.23 \pm 3.89^{\mathrm{b}}$ \\
P3'a (S) & $98.51 \pm 2.31^{\mathrm{a}}$ & $79.60 \pm 5.19^{\mathrm{b}}$ \\
\hline
\end{tabular}

$\overline{\mathrm{a}-\mathrm{d}}$ Values within a column with different superscripts differ $(P<0.05)$. Each comparison was made by $\mathrm{pH}$ value (Tukey test).

${ }^{1}$ Each value is expressed as mean value $\pm \mathrm{SD}(\mathrm{n}=3)$.

${ }^{2}$ Letters i and a correspond to initial ( $\mathrm{pH}$ 6.66) and acidified ( $\left.\mathrm{pH} 4.6\right) \mathrm{pH}$ of cheese whey before pressurization, respectively. P1 corresponds to sample pressurized for 5 min at $600 \mathrm{MPa}, \mathrm{P} 2: 10$ min at $600 \mathrm{MPa}, \mathrm{P} 3: 15 \mathrm{~min}$ at $600 \mathrm{MPa}, \mathrm{P}^{\prime}: 2 \times 5 \mathrm{~min}$ at $600 \mathrm{MPa}$, and $\mathrm{P} 3^{\prime}: 3 \times 5$ min at $500 \mathrm{MPa}$.

$\mathrm{pH}$ (6.66). Indeed, only $18 \pm 0.92 \% \beta$-LG was recovered in the pellet after 1 cycle of $5 \mathrm{~min}(\mathrm{P} 1 \mathrm{i})$ compared with $39 \pm 1.56$ for 3 cycles of $5 \mathrm{~min}$ (P3i) and $33 \pm$ 2.32 for 1 cycle of 15 min (P3'i). However, when whey was acidified before HHP treatment, the $\beta$-LG yields were similar regardless of the pressurization conditions tested, with an average of $90 \%$ (P1a to P3'a; $P<0.05$ ).

Broadly, the increase in number of cycles (P1, P2, and $\mathrm{P} 3)$ and duration of pressurization (P1, P2', and $\left.\mathrm{P} 3^{\prime}\right)$ had a significant effect on the composition of frac-

Table 3. $\beta$-Lactoglobulin purification degree and yields (\%) of pellets $(\mathrm{P})$ recovered from whey at different $\mathrm{pH}$ (initial and acidified) after pressure treatments $\left(\mathrm{P} 1, \mathrm{P} 2, \mathrm{P} 3, \mathrm{P} 2^{\prime} \text {, and } \mathrm{P} 3^{\prime}\right)^{1}$

\begin{tabular}{|c|c|c|c|}
\hline $\mathrm{pH}$ & Sample name ${ }^{2}$ & Yield (\%) & $\begin{array}{l}\text { Purification } \\
\text { degree }(\%)\end{array}$ \\
\hline Initial (6.66) & $\begin{array}{l}\text { WpHi (control) } \\
\text { WpHi (P) } \\
\text { P1i (P) } \\
\text { P2i (P) } \\
\text { P3i (P) } \\
\text { P2'i (P) } \\
\text { P3'i (P) }\end{array}$ & $\begin{array}{c}\mathrm{ND}^{3} \\
\mathrm{ND} \\
18.27 \pm 0.92^{\mathrm{a}} \\
30.02 \pm 3.33^{\mathrm{b}} \\
39.20 \pm 1.56^{\mathrm{c}} \\
20.31 \pm 2.88^{\mathrm{a}} \\
33.36 \pm 2.32^{\mathrm{b}}\end{array}$ & $\begin{array}{c}\text { ND } \\
\text { ND } \\
92.49 \pm 4.18^{\mathrm{a}} \\
96.38 \pm 3.50^{\mathrm{a}} \\
97.90 \pm 3.52^{\mathrm{a}} \\
99.55 \pm 7.41^{\mathrm{a}} \\
95.76 \pm 0.77^{\mathrm{a}}\end{array}$ \\
\hline Acidified (4.6) & $\begin{array}{l}\text { WpHa (control) } \\
\text { WpHa (P) } \\
\text { P1a (P) } \\
\text { P2a (P) } \\
\text { P3a (P) } \\
\text { P2'a (P) } \\
\text { P3'a (P) }\end{array}$ & $\begin{array}{c}\text { ND } \\
\text { ND } \\
88.06 \pm 1.78^{\mathrm{a}} \\
90.67 \pm 1.31^{\mathrm{a}} \\
91.96 \pm 0.72^{\mathrm{a}} \\
88.09 \pm 2.57^{\mathrm{a}} \\
90.42 \pm 3.52^{\mathrm{a}}\end{array}$ & $\begin{array}{c}\text { ND } \\
\text { ND } \\
97.54 \pm 0.47^{\mathrm{a}} \\
98.86 \pm 1.61^{\mathrm{a}} \\
98.07 \pm 1.69^{\mathrm{a}} \\
98.24 \pm 1.17^{\mathrm{a}} \\
98.71 \pm 1.90^{\mathrm{a}}\end{array}$ \\
\hline
\end{tabular}

$\overline{{ }^{a-c}}$ Values within a column with different superscripts differ $(P<0.05)$. Each comparison was made by $\mathrm{pH}$ value (Tukey test).

${ }^{1}$ Each value is expressed as mean value $\pm \mathrm{SD}(\mathrm{n}=3)$.

${ }^{2}$ Letters i and a correspond to initial $(\mathrm{pH} \mathrm{6.66)}$ and acidified $(\mathrm{pH} \mathrm{4.6)} \mathrm{pH}$ of cheese whey before pressurization, respectively. P1 corresponds to sample pressurized for 5 min at $600 \mathrm{MPa}, \mathrm{P} 2: 10$ min at $600 \mathrm{MPa}, \mathrm{P} 3: 15 \mathrm{~min}$ at $600 \mathrm{MPa}, \mathrm{P}^{\prime}: 2 \times 5 \mathrm{~min}$ at $600 \mathrm{MPa}$, and $\mathrm{P} 3^{\prime}: 3 \times 5$ min at $600 \mathrm{MPa}$.

${ }^{3}$ Not determined: purification and yield could not be measured because no pellet was produced in those conditions. 
tions (supernatants and pellets) from whey solutions only when solutions were pressure-treated at initial $\mathrm{pH}$ (6.66). However, at this $\mathrm{pH}$, both $\alpha$-LA and $\beta$-LG fractions showed the lowest purification degrees and yields. Inversely, pressurization parameters did not affect purification degree and yields when both WP were pressurized at $\mathrm{pH}$ 4.6. The acidification of whey at $\mathrm{pH}$ 4.6 before its pressurization at $600 \mathrm{MPa}$ for 5,10 , or 15 min resulted in the highest values of $\alpha$-LA purification. Moreover, time of pressurization had no effect on purification or yield of $\alpha-\mathrm{LA}$ and $\beta-\mathrm{LG}$. Therefore, the 5 -min treatment is the most interesting from an economic perspective. With $75 \%$ purity and $95 \%$ yield of $\alpha-\mathrm{LA}$, this treatment could achieve higher purification and yield than those obtained by chromatography (90.6 and $47.9 \%$, respectively, using affinity) or filtration (80 and $10 \%$, respectively, using ultrafiltration; Gurgel et al., 2000; Holland et al., 2012). Moreover, the approach presented in this study could reach the highest degree of purification and highest yield, similar to those obtained from a combination of affinity chromatography and selective precipitation (90 and $80 \%$, respectively) or of cation exchange chromatography and ultrafiltration (97.4 and 80\%, respectively; Blomkalns and Gomez, 1997; Geng et al., 2015). However, comparisons of protein purities and yields should be done carefully because the method of quantification and the degree of denaturation of the initial protein may differ from one work to the other.

Nevertheless, HHP is considered to be much more environmentally friendly than the other mentioned technologies. As described in our previous work, even though HHP is a batch process with significantly higher operating and maintenance costs, several strategies are currently being developed to minimize the associated energy consumption (Pereira and Vicente, 2010; Rodriguez-Gonzalez et al., 2015; Wang et al., 2016). Very recently, a semi-batch HHP system (Hiperbaric 1050 Bulk, Hiperbaric, Miami, FL) that comprises 2 storage tanks for initial and final products has been launched. It allows treatment of large quantities of liquid in semicontinuous mode and can be easily incorporated into an industrial line. Among the innovative approaches to decrease the environmental impacts of conventional methods, this technology remains relatively more expensive. However, to produce high value-added product such as purified protein ( $\alpha$-LA in this study), this approach has potential but needs further investigation.

\section{CONCLUSIONS}

Our results demonstrated that HHP treatment $(600$ $\mathrm{MPa}, 5 \mathrm{~min}$ ) of acidified ( $\mathrm{pH} 4.6)$ whey generated 2 specific fractions enriched in $\alpha$-LA (soluble) or $\beta$-LG (precipitate). The HHP treatment of acidified whey resulted in the soluble fraction with the highest degree of $\alpha$-LA purification (75\%) and yield (95\%), respectively. The same conditions provided the insoluble (pellet) fraction with the highest degree of purification (98\%) and yield $(88 \%)$ of $\beta$-LG. Overall, our results demonstrate a promising application of an emerging and nonthermal HHP-based method to produce the industrially valuable proteins $\alpha$-LA and $\beta$-LG from cheese whey.

\section{ACKNOWLEDGMENTS}

The authors acknowledge Fromagerie Bergeron (Saint-Antoine-de-Tilly, QC, Canada) for kindly providing the gouda-like cheese whey and are grateful for the financial support from the Natural Sciences and Engineering Research Council of Canada (NSERC), Discovery Grant Program. We also thank Véronique Perreault, Diane Gagnon, and Sophie Fortin (Food Science Department, Université Laval) for their technical support, and Abigail L. Krentz (Food Science Department, The Ohio State University, Columbus, $\mathrm{OH}$ ) for proofreading this manuscript. The authors have not stated any conflicts of interest.

\section{REFERENCES}

AOAC International. 2005. Official Methods of Analysis. 18th ed. Methods 990.20, 991.20, 930.29, and 998.06. AOAC International, Gaithersburg, MD.

Arunkumar, A., and M. R. Etzel. 2013. Fractionation of $\alpha$-lactalbumin from $\beta$-lactoglobulin using positively charged tangential flow ultrafiltration membranes. Separ. Purif. Tech. 105:121-128. https://doi .org/10.1016/j.seppur.2012.12.018.

Bhattacharyya, J., and K. P. Das. 1999. Molecular chaperonelike properties of an unfolded protein, $\alpha_{\mathrm{s}}$-casein. J. Biol. Chem. 274:15505-15509. https://doi.org/10.1074/jbc.274.22.15505.

Blomkalns, A. L., and M. R. Gomez. 1997. Purification of bovine $\alpha$-lactalbumin by immobilized metal ion affinity chromatography. Prep. Biochem. Biotechnol. 27:219-226. https://doi.org/10.1080/ 10826069708001280.

Boland, M., H. Singh, and A. Thompson. 2014. Milk Proteins: From Expression to Food. 2nd ed. Elsevier Academic Press, London, UK.

Bylund, G., B. Malmgren, A. Holanowski, M. Hellman, G. Mattson, B. Svensson, H. Pålsson, K. Lauritzen, T. Vilsgaard, E. Verweij, E. Bronsveld, N. Adamson, J. Perse, P. Kouroutsidis, J. Mathisson, F. Franz, C. Svensson, and U. Rehn. 2003. Dairy Processing Handbook. Tetra Pak, Lund, Sweden. https://dairyprocessinghandbook .com.

Considine, T., H. A. Patel, S. G. Anema, H. Singh, and L. K. Creamer. 2007. Interactions of milk proteins during heat and high hydrostatic pressure treatments - A review. Innov. Food Sci. Emerg. Technol. 8:1-23. https://doi.org/10.1016/j.ifset.2006.08.003.

DeSilva, K., R. Stockmann, and G. W. Smithers. 2003. Isolation procedures for functional dairy components - Novel approaches to meeting the challenges. Aust. J. Dairy Technol. 58:148-152.

Dufour, E. 2004. Structures des protéines solubles majeures. Pages 343-390 in Minéraux et Produits Laitiers. F. Gaucheron, ed. Tec \& Doc, Lavoisier, Paris, France.

El-Sayed, M. M. H., and H. A. Chase. 2011. Trends in whey protein fractionation. Biotechnol. Lett. 33:1501-1511. https://doi.org/10 .1007/s10529-011-0594-8. 
Gaucheron, F. 2004. Minéraux et Produits Laitiers. Tec \& Doc, Lavoisier, Paris, France.

Geng, X. L., A. Tolkach, J. Otte, and R. Ipsen. 2015. Pilot-scale purification of $\alpha$-lactalbumin from enriched whey protein concentrate by anion-exchange chromatography and ultrafiltration. Dairy Sci. Technol. 95:353-368. https://doi.org/10.1007/s13594-015-0215-8.

Ghisaidoobe, A. B. T., and S. J. Chung. 2014. Intrinsic tryptophan fluorescence in the detection and analysis of proteins: A focus on Förster resonance energy transfer techniques. Int. J. Mol. Sci. 15:22518-22538. https://doi.org/10.3390/ijms151222518.

Gurgel, P. V., R. G. Carbonell, and H. E. Swaisgood. 2000. Fractionation of whey proteins with a hexapeptide ligand affinity resin. Bioseparation 9:385-392. https://doi.org/10.1023/A: 1011191818927.

Hall, D., R. Zhao, I. Dehlsen, N. Bloomfield, S. R. Williams, F. Arisaka, Y. Goto, and J. A. Carver. 2016. Protein aggregate turbidity: Simulation of turbidity profiles for mixed-aggregation reactions. Anal. Biochem. 498:78-94. https://doi.org/10.1016/j.ab.2015.11 .021 .

Holland, B., J. Kackmar, and M. Corredig. 2012. Short communication: Isolation of a whey fraction rich in $\alpha$-lactalbumin from skim milk using tangential flow ultrafiltration. J. Dairy Sci. 95:56045607. https://doi.org/10.3168/jds.2012-5399.

Huppertz, T., P. F. Fox, and A. L. Kelly. 2004. High pressure-induced denaturation of $\alpha$-lactalbumin and $\beta$-lactoglobulin in bovine milk and whey: A possible mechanism. J. Dairy Res. 71:489-495. https: //doi.org/10.1017/S0022029904000500.

Huppertz, T., T. Vasiljevic, B. Zisu, and H. Deeth. 2019. Novel processing technologies: Effects on whey protein structure and functionality. Pages 281-334 in Whey Proteins: From Milk to Medicine. Elsevier Academic Press, London, UK.

ISO. (International Organization for Standardization). 2008. ISO 5545:2008 (IDF 90:2008): Rennet casein and caseinates-Determination of ash (reference method). ISO, Geneva, Switzerland.

Lakowicz, J. R. 2006. Principles of Fluorescence Spectroscopy. 3rd ed. Springer-Verlag, New York, NY.

Laneuville, S. 2004. Étude de l'interaction associative entre la $\beta$-lactoglobuline et le xanthane natif ou le xanthane traité aux hautes pressions hydrodynamiques. PhD Thesis. Department of Food Sciences, Université Laval, Quebec City, QC, Canada.

Lima, J. C., F. A. V. Seixas, J. S. R. Coimbra, T. C. Pimentel, C. E. Barão, and L. Cardozo-Filho. 2019. Continuous fractionation of whey protein isolates by using supercritical carbon dioxide. J. CO2 Util. 30:112-122. https://doi.org/10.1016/j.jcou.2019.01.008.

Marciniak, A.. S. Suwal, G. Brisson, M. Britten, Y. Pouliot, and A. Doyen. 2018a. Studying a chaperone-like effect of beta-casein on pressure-induced aggregation of beta-lactoglobulin in the presence of alpha-lactalbumin. Food Hydrocoll. 84:9-15. https://doi.org/10 .1016/j.foodhyd.2018.05.038

Marciniak, A., S. Suwal, G. Brisson, M. Britten, Y. Pouliot, and A. Doyen. 2019. Evaluation of casein as a binding ligand protein for purification of alpha-lactalbumin from beta-lactoglobulin under high hydrostatic pressure. Food Chem. 275:193-196. https://doi .org/10.1016/j.foodchem.2018.09.110.
Marciniak, A., S. Suwal, M. Britten, Y. Pouliot, and A. Doyen. 2018b. The use of high hydrostatic pressure to modulate milk protein interactions for the production of an alpha-lactalbumin enrichedfraction. Green Chem. 20:515-524. https://doi.org/10.1039/ C7GC03428H.

McSweeney, P. L. H., and J. A. O'Mahony. 2016. Advanced Dairy Chemistry: Volume 1B: Proteins: Applied Aspects. Springer, New York, NY.

Meng, X., Y. Bai, J. Gao, X. Li, and H. Chen. 2017. Effects of high hydrostatic pressure on the structure and potential allergenicity of the major allergen bovine $\beta$-lactoglobulin. Food Chem. 219:290296. https://doi.org/10.1016/j.foodchem.2016.09.153.

Patel, H. A., H. Singh, S. G. Anema, and L. K. Creamer. 2006. Effects of heat and high hydrostatic pressure treatments on disulfide bonding interchanges among the proteins in skim milk. J. Agric. Food Chem. 54:3409-3420. https://doi.org/10.1021/jf052834c.

Pereira, R. N., and A. A. Vicente. 2010. Environmental impact of novel thermal and non-thermal technologies in food processing. Food Res. Int. 43:1936-1943. https://doi.org/10.1016/j.foodres .2009.09.013.

Rodiles-López, J. O., I. J. Arroyo-Maya, M. E. Jaramillo-Flores, G. F. Gutiérrez-López, A. Hernández-Arana, G. V. Barbosa-Cánovas, K. Niranjan, and H. Hernández-Sánchez. 2010. Effects of high hydrostatic pressure on the structure of bovine $\alpha$-lactalbumin. J. Dairy Sci. 93:1420-1428. https://doi.org/10.3168/jds.2009-2786.

Rodriguez-Gonzalez, O., R. Buckow, T. Koutchma, and V. M. Balasubramaniam. 2015. Energy requirements for alternative food processing technologies - Principles, assumptions, and evaluation of efficiency. Compr. Rev. Food Sci. Food Saf. 14:536-554. https:// doi.org/10.1111/1541-4337.12142.

Royer, C. A. 1995. Approaches to teaching fluorescence spectroscopy. Biophys. J. 68:1191-1195. https://doi.org/10.1016/S0006 $-3495(95) 80295-\mathrm{X}$.

Smithers, G. W. 2015. Whey-ing up the options-Yesterday, today and tomorrow. Int. Dairy J. 48:2-14. https://doi.org/10.1016/j .idairyj.2015.01.011.

Wang, C. Y., H. W. Huang, C. P. Hsu, and B. B. Yang. 2016. Recent advances in food processing using high hydrostatic pressure technology. Crit. Rev. Food Sci. Nutr. 56:527-540. https://doi.org/10 $.1080 / 10408398.2012 .745479$.

Yver, A. L., L. M. Bonnaillie, W. Yee, A. Mcaloon, and P. M. Tomasula. 2011. Fractionation of whey protein isolate with supercritical carbon dioxide-process modeling and cost estimation. Int. J. Mol. Sci. 13:240-259. https://doi.org/10.3390/ijms13010240.

\section{ORCIDS}

Julien Chamberland () https://orcid.org/0000-0001-5674-8198

Yves Pouliot (ㄴ) https://orcid.org/0000-0002-8873-7394

Alain Doyen ํ https://orcid.org/0000-0001-9293-8036 